\title{
Students service learning experiencies in Mexican Microenterprises
}

\section{Mungaray-Lagarda, Alejandro; Ramírez-Angulo, Natanael; Osorio-Novela, Germán} Universidad Autónoma de Baja California, Mexico.

\begin{abstract}
This paper presents an experience of a service learning program in underprivileged Microenterprises. It shares the experience of Program for Research, Assistance and Teaching of Small Enterprises, an innovative model of assistance to deliver Business Development Services to low value added Microenterprises, including technical assistance and training with the participation of senior students, which act as advisers to the Microenterprises, implemented in the State of Baja California, Mexico, by The Autonomous University of Baja California. This program was propused as compensatory mechanism for the unemployment burden created by the low growth prospects. From 2009 to 2016, with about 1,500 students, the program has assisted, trained, and formalized in the tax institution about 11,300 individuals running microenterprises, which in addition, most of them have become subject to and has been given financial support by the goverment. The paper suggests that service learning programs with the participation of college students can play an important role both in supporting disadvantaged microenterprises and in providing meaningful learning experiences to students.
\end{abstract}

Keywords: Service learning; business development services; public policy. 


\section{Introduction}

Service-learning (SL) is an approach to learning-by-doing that highlights the social relevance of the work performed by universities. It can be regarded as an augmentation of the concept of Community Service (CS) with the inclusion of a learning component that may carry academic credits or may be part of a specific course requirement (Rhoads, 1997).The fundamental idea is that students learn and develop themselves through active participation in communitarian experiences organised and led by faculty, where they have the opportunity to apply the concepts and instruments recently acquired to help their community (Yates and Yuniss, 1999). More formally, SL is a method of experiential learning that links the classroom with the local community, and requires students to spend time in volunteer service and relate their experiences to the educational knowledge they see in the classroom (McGoldrick, 1998). Dewey can be considered as a pioneer in integrating experiential learning into education and thereby constitutes a background for the SL pedagogy. He argued that the lessons learned when students are concerned for the welfare of others provided not only an educational stimulus but also an expansion of their horizons and encouragement to take responsibility for their fellow humans (Dewey, 1938).

This approach has been added to other modern education mechanisms, which focus on restructuring the learning processes within the classroom, even from basic levels. One of them is aimed to encourage entrepreneurship and creativity among primary school pupils than they acquire entrepreneurial skills through running a business. This type of teaching help the entrepreneurship education stakeholders increase the effectiveness of entrepreneurship education programmes and actions aimed at promoting firm creation (Barba \& Atienza, 2016). Another project is to restructure the traditional classroom, under a new design that improves the educational environment by modifying student seats, tables, equipment, location of the instructor etc., achieving an the active learning classroom, which increases understanding of the student, greater participation and communication with the instructor, improving levels of school achievement (Park \& Choi, 2014).

On the other hand, Business Development can be understood as a package of conditions providing the elements for the businesses to prosper in a market based economy, where several complementing institutions and organizations play a role. Perhaps the most acknowledged elements for small business are financial and non-financial services. The former is compounded by the well-known models of Microfinance, as well as other services like deposits, insurance, and payment services. The later includes a broad range of services attempting to provide the entrepreneurs some basic assets for livelihood, particularly human capital, by developing skills and knowledge (Carney, 1998). These services are often referred to as Business Development Services (BDS): training, technology transfer, marketing assistance, business advice, mentoring and information, which are aimed at helping the entrepreneurs improve the performance of their businesses (Goldmark, 1996). 
The Program for Research, Assistance and Teaching of Small Enterprises (PRATS) was created as a CS program in 1999 at the Autonomous University of Baja California (UABC), Tijuana, Mexico, with the participation of few students and microenterprises (MEs), but was implemented systematically since 2001 with the support of funds. In the most general way, PRATS has been designed to take advantage of the human and physical capital, as well as other intangible assets already in possession of the Public Universities System. It also attempts to fit the organization and institutional arrangements governing HEI, to the growing concern of the government and other non-government organizations about microenterprise development, and on sustainable ways to care for such a broad sector of society. Thus, resources such as faculty, students, networks, facilities, equipment, and other assets become more socially profitable by being optimally used in favor of society.

The main objectives of PRATS are delivering BDS in situ at no cost to unprivileged enterprises, conduct research on small firm development, and build up a model of teaching, and learning for students in the field of Economics, Business, Management, and surrounding disciplines. From the HEI perspective, PRATS constitutes a SL approach of teaching, encouraging the students' professional learning, experience and entrepreneurial skills; and a research-action method of doing research while providing care, thus not only empowering their linkage to society, and the teaching-learning process, but also making pertinent research (Mungaray, Ramírez-Urquidy, Texis, Ledezma \& Ramírez, 2008)

\section{The Program for Research, Assistance and Teaching of Small Enterprises}

The program provides the students the opportunity to apply their profession, access their social context, and develop a feeling of affection for their community and the value of solidarity (Mungaray and Sanchez, 2003). Students in PRATS attend the microenterprises for a twelve-week period and work as consultants, developing a complete program of data collection, processing and analysis, ending up in a report on the enterprise's performance to be provided to the entrepreneurs, and comments for improvement. While the students involve with the entrepreneurs, they transfer knowledge, economic and business concepts, and management and technical skills, allowing these agents acquire some human capital that they would have never gotten otherwise. In addition, the in situ assistance constitutes also an on-call response to specific problems the entrepreneurs confront with, where the students can serve as a consultant during the weeks they engage in the enterprise operation.

The academic, educational and social impact of the project has been attractive to NGO's, government organizations and some universities, which have funded aiming to transform PRATS into a model that enable other HEI to reproduce it as SL program in their respective geographical regions. Thus, the State Government of Baja California, Mexico, trough the Ministry of Economic Development, and the Autonomous University of Baja California 
(UABC) have implemented a comprehensive program of microenterprise assistance since 2009, based on the PRATS designed by UABC. This program has become a public policy with the collaboration between the State Government and the State Public University (UABC) (Mungaray, Ramírez, M., \& Ramírez N., 2014).

\subsection{Student Recruitment and training}

The model incorporates students in the fields of management and accounting, business, economics, marketing, international business and other related fields, who have an interest in helping MEs. The program coordinators evaluate students enrolment requests to enter and conduct meetings with the interested students. These meetings are intended to familiarize the students and describe the main components of the program. The meeting also intends to emphasize the importance of the students work in MEs and also the importance of their participation in the project as a State Government Public Policy to support the MEs and promote employment.

The project offers a training program for participating students. The training program is intended to cover some of the basic elements that students apply in MEs in order to standardize the framework of concepts among students. The topics concern the development of MEs. The experience during the existence of the program plays an important role in providing real cases, and concepts on business, finance, economics, markets and business regulations, among other related topics. The training program reviews many of the skills and techniques learned by the students during their careers, using real data from MEs that were previously assisted. The training phase plan also establishes what students perform in business.

\subsection{Selection of Microenterprises}

One of the disadvantages of some support programs is that entrepreneurs should attend the service provider's locations, and not the other way around. This becomes an important element discouraging the MEs to receive services, as they have to leave their tasks and routines in their business. Given that entrepreneurs in these businesses develop multiple tasks such as management, production, sales, among others, leaving their businesses produces a considerable opportunity cost. To overcome this, the students themselves seek the MEs in various ways, either by visiting slums door to door, going to community centers, schools and other infrastructure in neighborhoods. The disadvantaged MEs operate within their homes in what is known as family workshops. Other MEs are more visible as they have separate from home in independent workshops. Other contact mechanisms are the State Government office and University facilities.

The MEs eligible for the program are those that are considered underprivileged or low value added, operating in the informal sector, whose sole owner performs many of the 
relevant activities in the business, predominantly employ family members, and have no separation between the resources of the business and home. These units can be considered as self-employment enterprises and originate from precarious macroeconomic conditions, recession and unemployment. Besides, they also originate because their owners lack of better working alternatives because they have a low level of education and training (Mungaray et al., 2014).

While officially MEs in Mexico are those units no greater than 10 employees, typically micro social base have an average of 2 to 5 workers and where the family plays an important role. This definition takes practice using regulatory criteria for eligibility that are applied by students in their search. According to this view, MEs should have no official or institutional support by some other program, lack of formal registration before tax authority, lack of accounting or formal administrative system, and owners should have primary education, secondary, or high school at maximum. These criteria make easier to reach the most modest MEs and ensure the relevance of the work done by students, and realize the social profitability of the project.

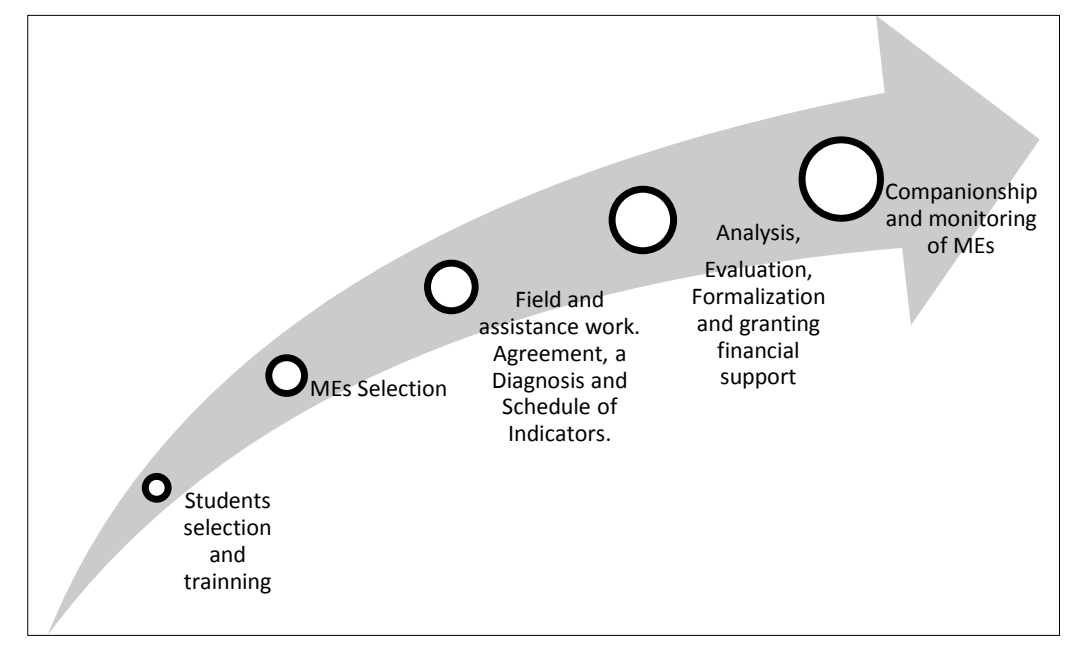

Figure 1. Model of assistance. Source: Mungaray, et al. (2014). 


\subsection{Assistance and training to micro individual and groups}

The work of supporting MEs requires several visits and interviews with the entrepreneur, some of which are carried out either as a group training in workshops. Students enrolled in the programne attend the microenterprises for a three months period and work as consultants. The students' consultancy is provided within a framework of instruments and tools that formalise the relation between the entrepreneurs and the University. This framework characterises the enterprise profile, guides the data collection and report generation, and defines indicators to assess the productive units.

There are three main tools: an Agreement, a Diagnosis and Schedule of Indicators. The Agreement is a written document which formalises the participation of the MEs in the programme. The Diagnosis is a comprehensive survey applied by the students at the beginning of the assistance phase which constitutes a baseline to start intervention and includes preliminary information about the MEs. The Schedule of Indicators is a record of the operations of the MEs and indicators monitored on a daily or weekly basis. These include sales, output, costs, usage of inputs, and wages, among other variables, which are then used to construct an enterprise financial and economic profile (Mungaray et al., 2008)

\subsection{Analysis, evaluation, formalization}

At the end of the assistance period in the MEs, students analyze the data they collected in order to assess the enterprise formally for a written report. This stage is developed by the support of the Copy righted Software for Microenterprise Assistance (SAM). The software generates economic and financial reports such as Cost Analysis, Income Statement, Net Cash Flows, Proforma Income Statement, and Analysis of Financial Ratios and Break-Even Point. The software not only allows registering and storing socioeconomic information of the MEs engaged in the program, such as personal data, education, experience, among others, but also storing relevant data on the MEs such as capital, assets, financial structure, strategies, revenues, costs and expenses; and generates financial and economic reports such as cost Analysis, Statements of Income, Net Cash Flows, Proforma Income Statements, Financial Ratios Analysis, Breakeven Analysys and the results of the Economic and financial Evaluation.

\subsection{Accompaniment, $\mathrm{ME}$ assistance, and support and the Follow-Up.}

Once the MEs have taken on the challenge of being in a context of formality, and received financial support, a process that lasts three months from initial contact, the program continues to a stage accompaniment to enhance the ME position in the context of formality and the new obligations that the MEs have before the Tax Authority. In this stage, the assistance process continues on MEs organization and the entrepreneurs tax compliance; the data collection through SAM continues. Besides, the MEs training is intensified by two 
more workshops on Finance, and Marketing and Security issues in the Business. These workshops are intended for the entrepreneur to learn about to how to apply for a finance, finance requirements, implications of the enterprise leverage, funding amount, interest rate, period of grace, the concept of risk, opportunity cost, short and long term inventory investment or machinery and equipment, sales, income, cost of Sales, salary, sales strategies, product differentiation, cross sales, advertising, competition analysis, customer service, hygiene in production, among other concepts. In general, the entrepreneurs learn through these the importance of microfinance, planning, financing, analyzing competition, and other concepts.

\section{Results}

The program provided support to 11,308 microenterprises in urban and rural areas across the state, from 2009 to 2016. This amount of MEs were assisted, trained and supported with financial resources. They were, in fact, incorporated into the formal world, by promoting registration before the tax authority under the small taxpayer regime. In sum, these enterprise received training and were formalized and received nonrepayable financial support for more than 28 million pesos ( 2.2 million dollars approximately). The program also has incorporated 1,484 students who worked as consultant and helped the entrepreneurs to reach formality in addition to training. It is important to note that the program has benefited women entrepreneurs, since $73 \%$ of the supported entrepreneurs had this gender. In the future, the challenge is for MEs to be self-sustaining with organization, in addition to that the program should be transferred for free. It is a great challenge. It is also argued that students' learning is fostered by a method of teaching which is based on well established theories of learning. Evidence of the helpfulness of students'advice to MEs may be considered as one, rather demanding, way of measuring their learning.

Table 1. Supported microenterprise and students in the program of assitence, 2009-2016

\begin{tabular}{ccccc}
\hline Concept & $\mathbf{2 0 0 9 - 2 0 1 3}$ & $\mathbf{2 0 1 4}$ & $\mathbf{2 0 1 5}$ & $\mathbf{2 0 1 6}$ \\
\hline Supported MEs & 10,047 & 619 & 424 & 218 \\
$\begin{array}{c}\text { Participating } \\
\text { Students }\end{array}$ & 1,302 & 77 & 62 & 43 \\
\hline
\end{tabular}




\section{Concluding remarks}

The results of the application of this program-policy for microenterprise development, suggest the possibility to provide effective training, assistance for formalization and business development services from a methodology and the participation of students. It has also shown that collaborative schemes, in this case, government, universities and microenterprises, can result in effective public policies supported by various actors, for the support the the small scale of these MEs requires. The evaluation of the policy has illustrated that not only that more than 11,300 MEs were formalized and trained, but also, it has shown the possibility that a selection of these businesses can aspire to higher levels of development derived from deepening in training, differentiated support and access to microfinance. The results suggest that the supported MEs not only transited to operate under a formal context and rules, but those who have transited successfully trough higher stages of business training under the program, has achieved better growth levels in sales and profits. This is a cornerstone in improving microenterprise prospects and welfare. The program did not measure learning of students directly, this is part of a future research agenda; rather it provided an assessment of the efficacy of the SL programme in achieving its goal.

This experience of program for microenterprise development by students illustrates what is possible to achieve socially by the collaboration between microentrepreneurs, universities and government. This collaboration has resulted in significant social benefits to individuals running MEs, students and effectiveness of institutions. This experience may be useful to other regions of the country.

\section{References}

Carney, D. (1998). Sustainable Rural Livelihoods, what contribution can we make?, London: DFID.

Barba-Sanchez, V. \& Atienza-Sahuquillo, C. (2016). The development of entrepreneurship at school: the Spanish experience. Education and Training, 58(7-8), 783-796

Dewey, J. (1938). Experience and Education, New York: Collier Books.

Goldmark, L. (1996). Business Development Services: A Frame Work for Analysis. Working Paper No. MIC-101. Washington, D.C.

McGoldrick, K. (1998). Service-Learning in Economics: A Detailed Application. Journal of Economic Education, 24(4), 365-76.

Mungaray, A., Ramírez, M., \& Ramírez, N. (2014). El programa de asistencia microempresarial y la red de microempresas de base social: una política pública en apoyo a microempresas, in: A. Mungaray, N. Ramírez, \& M. Ramírez (eds) Políticas públicas para el desarrollo microempresarial en Baja California, México: Miguel Ángel Porrua-UABC. 
Mungara, A., Ramírez-Urquidy, M., Texis, M., Ledezma, D., \& Ramírez, N. (2008). Learning economics by servicing: a Mexican experience of service-learning in microenterprises. International Review of Economics Education, 7(2), 19-38.

Mungaray A. \& Sanchez M. (2003). The Impact of Service Projects on Micro-Enterprises in Mexican Marginalised Communities, in: H. Perold, S. Stroud \& M. Sherraden (eds) Service Enquiry: Service in the 21st.Century, The Global Service Institute.

Park, E. L. \& Choi, B. K. (2014). Transformation of classroom spaces: Traditional versus active learning classroom in colleges. Higher Education, 68, 749-771.

Rhoads, R. (1997). Community Service and Higher Learning: Exploration of the Caring Self, New York: Sate University of New York Press.

Yates, M. \& Yuniss, J. (1999). Promoting Identity development:Ten ideas for school based service learning programmes, in: J.Claus \& C.Ogden (eds) Service learning for youth empowerment and social change, New York: Peter Lang. 